\section{'Blake's Pride' Pear}

\author{
R.L. Bell ${ }^{1}$ and T. van der $\mathbf{Z w e t}^{2}$ \\ U.S. Department of Agriculture, Agricultural Research Service, Appalachian \\ Fruit Research Station, 45 Wiltshire Road, Kearneysville, WV 25430-9425
}

\section{Roland C. Blake ${ }^{3}$}

U.S. Department of Agriculture, Agricultural Research Service, Ohio Agricultural Research Service and Development Center, Wooster, OH 44691

Additional index words. Pyrus communis, cultivar, breeding, fire blight, Erwinia amylovora, disease resistance, fruit quality

'Blake's Pride' pear (Pyrus communis L.) is a new cultivar that combines a high degree of resistance to fire blight with aromatic, juicy fruit and consistent yield. Fire blight, caused by the bacterium Erwinia amylovora (Burr.) Winsl. et al., is the most serious disease of pears, and is presently endemic in most production regions of the northern hemisphere (van der Zwet and Beer, 1999). All major cultivars of commercial importance, as well as most of those available to home orchardists, are highly susceptible to this devastating bacterial disease (Bell, 1991; van der Zwet and Beer, 1999). The high degree of resistance observed in response to epiphytotic infections has been confirmed by artificial inoculation tests. 'Blake's Pride' was approved for joint release by the U.S. Dept. of Agriculture and The Ohio State Univ., Ohio Agricultural Research and Development Center (OARDC), in 1998 as a fresh-market pear for commercial growers and home orchards. It was named in honor of Dr. Roland Blake, who participated in the USDA, ARS pear breeding program at OARDC from 1967 to 1984.

\section{Origin}

'Blake's Pride' is derived from a cross of US 446 x US 505, made in 1965 by H.J. Brooks (Fig. 1). The original seedling tree, identified by the progeny-seedling number OHUS 66131-021, was selected in 1976 from a seedling orchard at OARDC, Wooster, Ohio, by R.C. Blake and T. van der Zwet. 'Blake's Pride' is derived entirely from Pyrus commu-

Received for publication 6 Aug. 2001. Accepted for publication 16 Feb. 2002. We thank H.J. Brooks for his contributions to the development of this cultivar, the administration and staff of The Ohio State University's Ohio Agricultural Research and Development Center for their cooperative role, and Wayne Zook, Greg Brenneman, John Walter, and Roger Lewis for providing technical assistance. We also thank Dr. Kenneth Eastwell and Mr. William Howell and their staff at the National Research Support Project No. 5, Washington State Univ., for providing virus and phytoplasm testing. Mention of a trademark, proprietary product, or vendor does not constitute a quarantee or warranty of the product by the U.S. Dept. of Agriculture and does not imply its approval to the exclusion of other products or vendors that also may be suitable.

${ }^{1}$ Research Horticulturist.

${ }^{2}$ Research Plant Pathologist, retired.

${ }^{3}$ Research Horticulturist, deceased. nis germplasm. The original source of fire blight resistance for this cultivar is the old American cultivar, 'Seckel'. Subsequently, 'Blake's Pride' has been evaluated for fruit quality, fire blight resistance, and productivity in a replicated, but nonrandomized, second test trial of four trees propagated on 'Bartlett' seedling rootstock, and planted in 1978 at the USDA, ARS Appalachian Fruit Research Station (AFRS), Kearneysville, W.Va. (Bell and van der Zwet, 1993). It is currently being evaluated in a randomized trial at AFRS, and by 10 cooperators at experiment stations and commercial orchards throughout the United States for range of adaptation, productivity, and postharvest fruit quality under a variety of environmental conditions and management systems.

\section{Description}

Fruit traits. The fruit of 'Blake's Pride' are symmetrical, and pyriform to round-pyriform in shape, equivalent to International Board for Plant Genetic Resources (IBPGR) shape ratings of 3.2 and 5.2 (Thibault et al., 1983; Fig. 2). Fruits are moderate in size, averaging 65.7 $\mathrm{mm}$ in diameter, and $79.5 \mathrm{~mm}$ in length (Table 1), similar to 'Bartlett'. Maximum values for the median of a sample for fruit diameter was $82 \mathrm{~mm}$, with a corresponding maximum length of $92 \mathrm{~mm}$. Mean individual fruit weight is similar to 'Bartlett' (Table 1). The stem is of medium length, of medium thickness, and upright. Skin undercolor when ripe is yellow, the finish is glossy, and $20 \%$ to $40 \%$ of the fruit surface is covered with a smooth, light tan, attractive russet, which is usually concentrated at the stem end. Harvest maturity at AFRS has occurred on 7 Sept., $\approx 2$ weeks after 'Bartlett'. The fruit will keep in air storage at $-1{ }^{\circ} \mathrm{C}$ for at least 3 months without core breakdown, superficial scald, or senescent scald. The maximum observed storage life of 'Blake's Pride' was $109 \mathrm{~d}$, while that observed for 'Bartlett' was $92 \mathrm{~d}$. The flesh texture is moderately fine, juicy, and buttery. Grit cells are moderately small and occur primarily around the core and in a thin layer under the skin, similar to 'Bartlett'. The flavor is subacid to sweet and, like 'Bartlett', 'Blake's Pride' is moderately aromatic; the character of the flavor and aroma is more similar to 'Doyenné du Comice' than 'Bartlett'. The fruit of 'Blake's Pride' and 'Bartlett' ripen to a soft, juicy, and buttery texture within 4 to $7 \mathrm{~d}$ following removal from at least 3 weeks of cold storage. In a single test in 1992, fruit of 'Blake's Pride' placed in a $20^{\circ} \mathrm{C}$ ripening room immediately after harvest required 13 to $17 \mathrm{~d}$, depending on the harvest date, to ripen.

Tree and production traits. The tree is moderate in vigor on 'Bartlett' seedling rootstock, and upright-spreading in habit. Flowers have white petals, and the anthers are pink to red. Full bloom at AFRS occurs $\approx 1$ to $4 \mathrm{~d}$ before 'Bartlett'. 'Blake's Pride' is self-incompatible, but reciprocally pollen-compatible with 'Bartlett', 'Beurre Bosc', 'Harrow Delight', and 'Packham's Triumph'. Pollencompatibility with other major cultivars has not been tested. Subjective yield ratings have been moderate to moderately high, with first crop 3 to 4 years after planting. Fruit are borne primarily on spurs, but also on terminal blossoms of lateral shoots, especially on young trees.

Disease Resistance. Epiphytotic (i.e., natural) infection in four individual trees planted in 1978 has been scored almost yearly, from 3 to 22 years of age, using the scoring system devised for mature trees by van der Zwet et al. (1970). Fire blight resistance is significantly greater than 'Bartlett', with rare infections extending no further than 1-year-old growth (Table 2). The worst individual tree score recorded in any year was 8 , with infection extending into 1-year-old wood.

Artificial inoculations were performed in the orchard at AFRS in 4 years using single isolates or mixtures of strains at equal concentrations. Inoculum preparation and inoculation procedures have been previously published (Bell et al., 1996). Details on isolates and concentrations, as well as data analysis, are given in Table 2. Frequencies of 'Bartlett' shoot infection were $100 \%$ in 1987,1999 , and 2000, and $95 \%$ in 1993, while values for 'Blake's Pride' were 50\%, 50\%, 90\%, and $80 \%$ for $1987,1993,1999$, and 2000 , respectively. Mean percent lesion length and mean age of infected wood did not vary significantly 


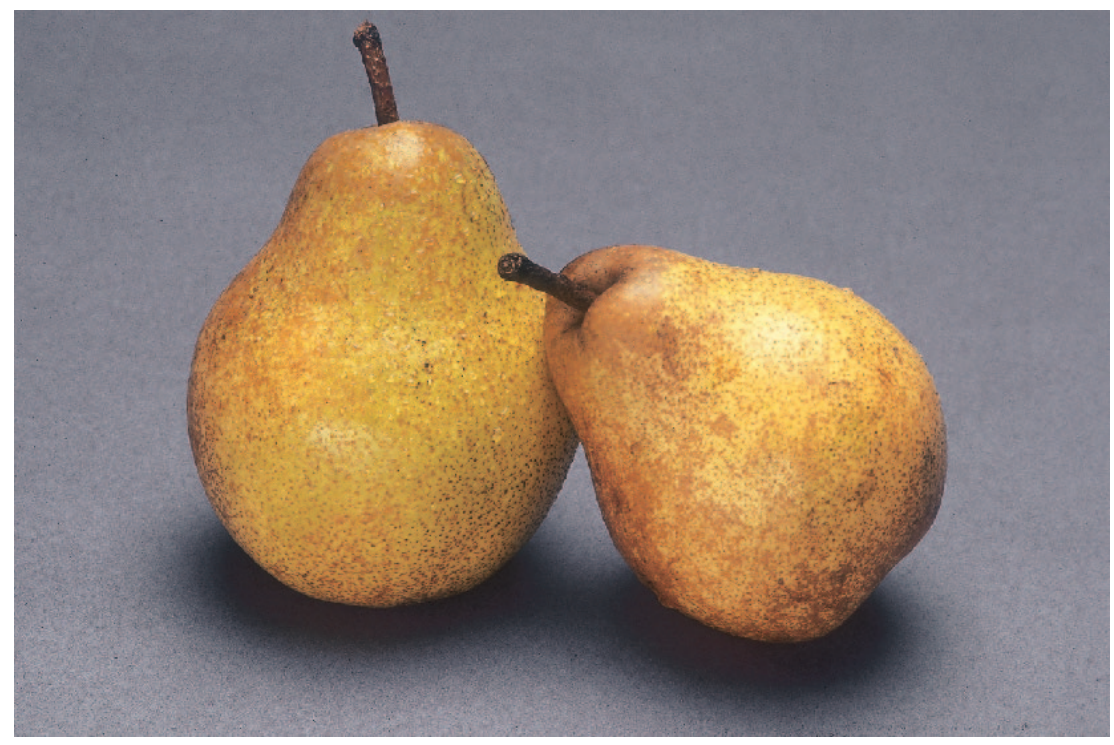

Fig. 2. Fruit of 'Blake's Pride'. among years for 'Blake's Pride'. For 'Bartlett', mean percent lesion length was significantly greater in $1993(167 \%)$ than in the other 3 years $(80 \%, 104 \%$, and $106 \%)$. Infection of 'Bartlett' wood was particularly severe in the year 2000, with all infections spreading into 3 year-old wood. In spite of the significant interactions, only the 4-year means are presented in Table 2. Even after 4 or 8 weeks, progression of most infections in 'Blake's Pride' had ceased. In comparison to the susceptible standard, 'Bartlett', shoot infections in 'Blake's Pride' were consistently significantly shorter, ceased progressing earlier, and only progressed into 1-year-old wood in a single shoot.

In 1999, blossoms of 'Blake's Pride' were artificially inoculated, and in 2000, blossoms of 'Blake's Pride' and 'Bartlett' were artificially inoculated. Details of the inoculation techniques and analysis of severity data are given in Table 3. In 1999, frequency of infection (defined as the number of infected blossoms expressed as a percent of total number of inoculated blossoms) and severity were recorded 12 d after inoculation. In 2000, frequency and severity of infection were scored at $11 \mathrm{~d}$ after inoculation, and severity was scored 21, 48, and $152 \mathrm{~d}$ after inoculation. A blossom was considered infected if even just the hypanthium showed necrosis. Frequency of blossom infection in year 2000 was analyzed using the chi-square test of SAS PROC FREQ (SAS Institute, 1990b).

Only one of 10 blossom clusters of 'Blake's Pride' was uninfected in both 1999 and 2000. In 2000, all blossoms on each of the 40 clusters of 'Bartlett' were infected, while all blossoms in 38 of 40 'Blake's Pride' clusters were infected. The chi-square test indicated no significant difference in frequency of blossom infection between the two cultivars. While the blossoms of 'Blake's Pride' are susceptible to infection, at least $50 \%$ of the infections progressed no further than the pedicel (Table 3 ), and at a slower rate than that observed in 'Bartlett' (data not presented), while all inoculations of 'Bartlett' progressed into wood at least 2 years old. Thus, the potential for loss of fruiting wood of 'Blake's Pride' is minimal.

Orchard survey data indicates that the cultivar is moderately resistant, but not immune to pear scab (Venturia pirinia Aderh.), and is susceptible to Fabraea leaf spot (Fabraea maculata Atk.) (data not presented). The 'Blake's Pride' budwood source tree at OARDC was tested by National Research Support Project No. 5 and found to be free of known viruses and the pear decline phytoplasm (W. Howell, personal communication).

\section{Availability}

Budwood of 'Blake's Pride' is limited and trees are not available from the U.S. Dept. of Agriculture. Interested nurseries and researchers should send requests for noncertified budwood to R.L.B. Pathogen-free certified budwood will be available from NRSP-5. Genetic material of this release will be deposited in the National Plant Germplasm System, where it will be available for research pur- 
Table 2. Fire blight development in response to epiphytotic and artificial shoot infection of 'Blake's Pride' and 'Bartlett'.

\begin{tabular}{lcccc}
\hline \hline & \multicolumn{4}{c}{ Cultivar } \\
\cline { 2 - 5 } Infection type & $\mathrm{n}$ & Blake's Pride & $\mathrm{n}$ & Bartlett \\
\hline Epiphytotic & 4 & $8.0 \pm 0.0 \mathrm{a}$ & 6 & $2.3 \pm 0.5 \mathrm{~b}$ \\
Shoot inoculation $^{\mathrm{y}}$ & & & & \\
$\quad$ Frequency $(\%)^{\mathrm{x}}$ & 90 & $68 \pm 10 \mathrm{~b}$ & 87 & $99 \pm 1 \mathrm{a}$ \\
\% Lesion length & & $14 \pm 2 \mathrm{a}$ & 87 & $114 \pm 19 \mathrm{~b}$ \\
Age of infected wood $^{\mathrm{v}}$ & 90 & $0.01 \pm 0.01 \mathrm{~b}$ & 87 & $1.3 \pm 0.6 \mathrm{a}$ \\
\hline
\end{tabular}

${ }^{\mathrm{z}}$ Lowest, i.e., most severe, rating of epiphytotic (i.e., natural) infection according to van der Zwet et al. (1970) in which $1=$ dead and $10=$ no symptoms. The number corresponding to $\mathrm{n}$ refers to the number of trees observed over a period of 12 years. Mean separation between cultivars was according to Fisher's protected $t$ test, following one-way analysis of variance performed with SAS PROC GLM (SAS Institute, 1990c).

${ }^{y}$ Actively growing shoot tips were inoculated in late May of 1987 using a mixture of E. amylovora isolates E2002 and Ea273, on 20 May 1993 using isolates MO-E-9, Ea273, and AFRS 581, on 6 June and 25 June of 1999 using isolates AFRS 554 and AFRS 581, and on 7 June 2000 using AFRS 554. Inoculum concentration was adjusted to $\approx 5 \times 10^{8} \mathrm{cfu} \cdot \mathrm{mL}^{-1}$ in 1987 , and to $1 \times 10^{8} \mathrm{cfu} \cdot \mathrm{mL}^{-1}$ concentration in all other years. Total shoot length, lesion length and age of infected wood were measured biweekly up to 8 weeks after inoculation in 1987 and 1993, after 16 weeks in 1999, and 21 weeks in 2000, after necrosis had ceased to progress. Final lesion length was divided by total shoot length to derive percent lesion length. Lesion length, percent lesion length, and arcsin transformed percentage data were analyzed for normality using the Shapiro-Wilk test in the NORMAL option of SAS PROC UNIVARIATE (SAS Institute, 1990a). In most cases, the arcsin transformation did not improve normality. Therefore, proportional lesion length and age of infected wood were analyzed without transformation, using SAS PROC GLM, with Type III sums of squares (SAS Institute, 1990c). A factorial treatment design with years and cultivars as fixed effects was used, least-square means and standard errors for the main effects were computed, and differences between the two cultivars tested by Fisher's protected $t$ test.

${ }^{x}$ Mean of 4 years data on percent of total number of inoculated shoots that developed lesions.

w\% Lesion length $=($ lesion length $/$ total shoot length $) \times 100$.

${ }^{v}$ Age of infected wood $(0=$ current-season's shoots, $1=1$-year-old shoots, etc. $)$.

Table 3. Fire blight infection in response to artificial blossom inoculation of 'Blake's Pride' and 'Bartlett'. ${ }^{\mathrm{T}}$

\begin{tabular}{|c|c|c|c|c|c|c|c|c|c|}
\hline \multirow[b]{2}{*}{ Year } & \multirow[b]{2}{*}{ Cultivar } & \multicolumn{7}{|c|}{ Infection severity score ${ }^{y}$} & \multirow{2}{*}{$\begin{array}{c}\text { Mean } \\
\text { severity }\end{array}$} \\
\hline & & 0 & 1 & 2 & 3 & 4 & 5 & 6 & \\
\hline$\overline{1999}$ & Blake's Pride & 1 & 0 & 8 & 0 & 0 & 1 & 0 & $2.1 \pm 0.4$ \\
\hline \multirow[t]{2}{*}{2000} & Blake's Pride & 1 & 0 & 20 & 0 & 18 & 1 & 0 & $2.9 \pm 0.2 \mathrm{a}$ \\
\hline & Bartlett & 0 & 0 & 0 & 0 & 0 & 21 & 19 & $5.5 \pm 0.1 \mathrm{~b}$ \\
\hline
\end{tabular}

${ }^{2}$ In 1999, five recently opened blossoms on each of 10 clusters were spray-inoculated with an equal mixture of E. amylovora isolates AFRS 554 and AFRS 581 at a concentration of $1 \times 10^{8} \mathrm{cfu} \cdot \mathrm{mL}^{-1}$, while in 2000 three blossoms on each of 40 clusters were individually inoculated by pipetting a $25-\mu \mathrm{L}$ drop of AFRS 554 inoculum at a concentration of $1 \times 10^{8} \mathrm{cfu} \cdot \mathrm{mL}^{-1}$ into the hypanthia. In 1999 , severity was recorded $12 \mathrm{~d}$ after inoculation. In 2000, severity of infection was scored 11, 21, 48, and 152 $\mathrm{d}$ after inoculation. Data presented are for the most severe score, up to $152 \mathrm{~d}$ postinoculation.

${ }^{y}$ Severity scale based upon tissue infected: $0=$ no infection; $1=$ receptacle; $2=$ pedicle; 3 = basal tissue of cluster; $4=$ spur or 1 -year-old wood; $5=$ spur bearing or 2 -year-old wood; $6=$ wood 3 years or older. Severity scores were analyzed using the Wilcoxon two-sample test of SAS PROC NPAR1WAY (SAS Institute, 1990c). Mean separation between cultivars for year 2000 (within column) according to the nonparametric analysis of variance $\mathrm{F}$ test. poses, including development and commercialization of new cultivars. It is requested that appropriate recognition be made if this germplasm contributes to the development of a new breeding line or cultivar.

\section{Literature Cited}

Bell, R.L. 1991. Pears (Pyrus). In: J.N. Moore and J.R. Ballington (eds.). Genetic resources of temperate fruit and nut crops. Acta Hort. 290. Chapter 14. Intl. Soc. Hort. Sci., Wageningen.

Bell, R.L. and T. Van der Zwet. 1993. New fire blight resistant advanced selections from the USDA pear breeding program. Acta Hort. 338:415-419.

Bell, R.L., T. van der Zwet, R.C. Blake, C.K. Chandler, and J.C. Scheerens. 1996. 'Potomac' pear. HortScience 31:884-886.

SAS Institute. 1990a. SAS procedures guide, Version 6, Third Ed. SAS Inst., Cary, N.C.

SAS Institute. 1990b. SAS/STAT user's guide, Version 6, Fourth Ed., Vol. 1. SAS Inst., Cary, N.C.

SAS Institute. 1990c. SAS/STAT User's Guide, Version 6, Fourth Ed., Vol. 2. SAS Inst., Cary, N.C.

Thibault, B., R. Watkins, and R.A. Smith (eds.). 1983. Descriptor list for pears (Pyrus). Intl. Board Plant Genet. Resources, Rome.

van der Zwet, T. and S.V. Beer. 1999. Fire blightIts nature, prevention, and control: A practical guide to integrated disease management. U.S. Dept. Agr., Agr. Inform. Bul. No. 631.

van derZwet, T., W.A. Oitto, and H.J. Brooks. 1970. Scoring system for rating the severity of fire blight in pear. Plant Dis. Rptr. 54:835-839. 